\title{
Installation of Very Broadband Seismic Stations to Observe Seismic and Cryogenic Signals, Antarctica
}

\author{
Won Sang Lee ${ }^{1 *}$, Yongcheol Park ${ }^{1}$, Sukyoung Yun ${ }^{1}$, Ki-Weon Seo ${ }^{1}$, Tae-Gyu Yee ${ }^{2}$, \\ Hanjin Choe ${ }^{1}$, Ho Il Yoon ${ }^{1}$, and Namyi Chae ${ }^{1}$ \\ ${ }^{1}$ Korea Polar Research Institute, Incheon 406-840, Korea \\ ${ }^{2}$ School of Earth and Environmental Sciences, Seoul National University, Seoul 151-747, Korea

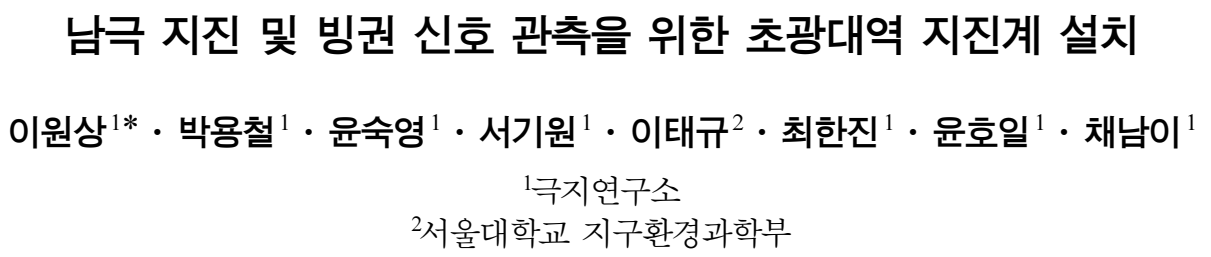

\begin{abstract}
Korea Polar Research Institute (KOPRI) has successfully installed two autonomous very broadband threecomponent seismic stations at the King George Island (KGI), Antarctica, during the 24th KOPRI Antarctic Summer Expedition (2010 2011). The seismic observation system is originally designed by the Incorporated Research Institutions for Seismology Program for Array Seismic Studies of the Continental Lithosphere Instrument Center, which is fully compatible with the Polar Earth Observing Network seismic system. The installation is to achieve the following major goals: 1. Monitoring local earthquakes and icequakes in and around the KGI, 2. Validating the robustness of seismic system operation under harsh environment. For further intensive studies, we plan to move and install them adding a couple more stations at ice shelf system, e.g., Larsen Ice Shelf System, Antarctica, in 2013 to figure out ice dynamics and physical interaction between lithosphere and cryosphere. In this article, we evaluate seismic station performance and characteristics by examining ambient noise, and provide operational system information such as frequency response and State-Of-Health information.
\end{abstract}

Keywords: very broadband seismic station, King George Island, Antarctica, system performance

요 약: 극지연구소는 2010 2011년 제 24차 남극하계탐사기간 동안 남극 킹조지섬에 3성분 초광대역 지진계를 성공 적으로 설치하였다. 미국 IRIS PASSCAL에서 개발한 지진관측시스템을 활용하였으며, 이는 POLENET 지진관측시스템 과 완벽히 호환된다. 지진계설치 및 운용의 목적은 크게 두가지로 나누어 지는데, 첫번째로 킹조지섬 주변의 지진 및 빙 권관련 신호를 관측하는데 있으며, 두번째로는 극한환경에서의 지진관측장비 성능검사이다. 관측이 성공적으로 수행된다 면, 다음 목표로 관측시스템의 추가확보를 통하여 남극반도 라르센 빙붕시스템과 같은 빙붕 주변으로 관측장소를 이동하 여 지권과 빙권간 상호작용을 이해하고, 빙권의 움직임등 동역학적인 해석을 위한 연구를 수행하고자 한다. 이 보고서에 서 우리는 지진파 배경잡음분석을 통하여 지진관측시스템 성능 및 특성 파악에 관한 내용과 관측시스템 운용관련 정보를 제공하고자 한다.

주요어: 초광대역 지진관측소, 남극 킹조지섬, 시스템 성능

\section{Introduction}

The Polar Regions are the places having unique and extreme aspects over various research areas and more sensitive to the effect of climate change rather than other regions

2012년 6월 18일 접수; 2012년 7월 13일 수정; 2012년 7월 17일 채택; *Corresponding author

E-mail: wonsang@kopri.re.kr

Address: Get-pearl Tower, Songdo Techno Park, Gaetbeol-ro Yeonsugu, Incheon 406-840, Korea in our planet. However, because of their inaccessibleness and harsh nature, the poles have remained insufficiently studied. During International Polar Year (IPY, 2007 2008), highly integrated and intensive efforts had been made through over 200 research projects, with thousands of scientists from over 60 nations examining a wide range of physical, biological and social research topics. POLENET (The Polar Earth Observing Network; http://www.polenet.org) is one of the research activities and a global network consisting of GPS and seismic stations for observing the Polar Regions. From 
these measurements, we could address important issues about ice sheet dynamics in a warming world.

In this article, we present a pilot experiment on autonomous polar seismic station technically supported by the Incorporated Research Institutions for Seismology (IRIS) Program for Array Seismic Studies of the Continental Lithosphere (PASSCAL).

\section{Installation}

In extreme environments such as Polar Regions, we should carefully prepare all components of a seismic observation system even cables, tiny connectors, etc. for successful installation and operation since air temperature easily goes down to $-20^{\circ} \mathrm{C}$ during the winter seasons. Especially, a robust power system is one of the key elements to ensure the entire system surviving during its operation period (year round) for an autonomous seismic station in the circumstances. We have deployed two portable seismic stations adjacent to the KOPRI's permanent seismic station (KSJ1), which has been operated since 2001, as a participant of the POLENET program in the King George Island (KGI) in December 2010 (KOPR1 and KOPR2, Fig. 1) equipped with very broadband seismometers, data loggers, and solar power system, etc. (Fig. 2), and they are well functioning at pre-

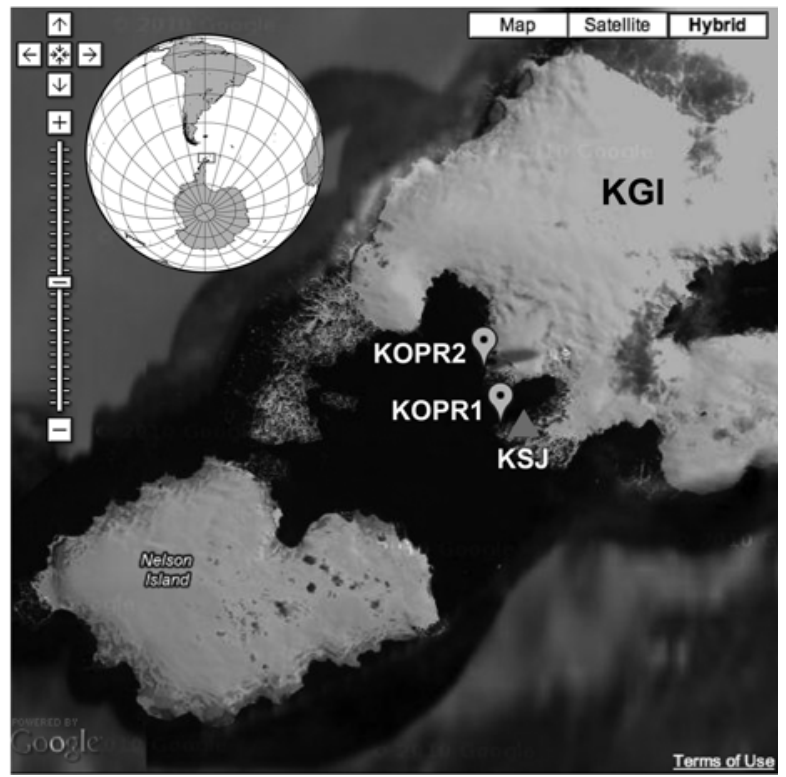

Fig. 1. Installation location of autonomous very broadband seismic stations (KOPR1 and KOPR2) at the KGI near the tip of the Antarctic Peninsula. KSJ stands for King Sejong Antarctic Base having been operated by KOPRI since 1988. The seismic stations are designed to detect not only local and global earthquakes but icequakes occurred in and around the KGI. sent. In this chapter, we present the details of each essential unit comprising the system.

\section{Seismometer}

The seismic observation system is built to primarily monitor local earthquakes associated with back-arc spreading and submarine volcanic activities in the Bransfield Strait, Antarctica. In addition, we are able to detect cryogenic events such as icequakes. According to the recent study by hydroacoustic observation (Dziak et al., 2010), both tectonic and cryogenic events are active in this region. In an attempt to observe the broadband signals and to functionally operate seismic stations under extreme cold temperature, we employed Trillium 240 three-component very broadband seismometers manufactured by Nanometrics which performance is fully verified with sufficient field operations conducted by the POLENET program. Fig. 3 demonstrates sensor responses in amplitude and phase as a function of frequency and guarantee that signals recorded within the frequency band between $240 \mathrm{sec}$ and $200 \mathrm{~Hz}$ are reliable to use without severe distortion. Considering operating temperature of the device $\left(-20{ }^{\circ} \mathrm{C}\right.$ to $50{ }^{\circ} \mathrm{C}$; http://www.nanometrics.ca) and the seasonal mini-

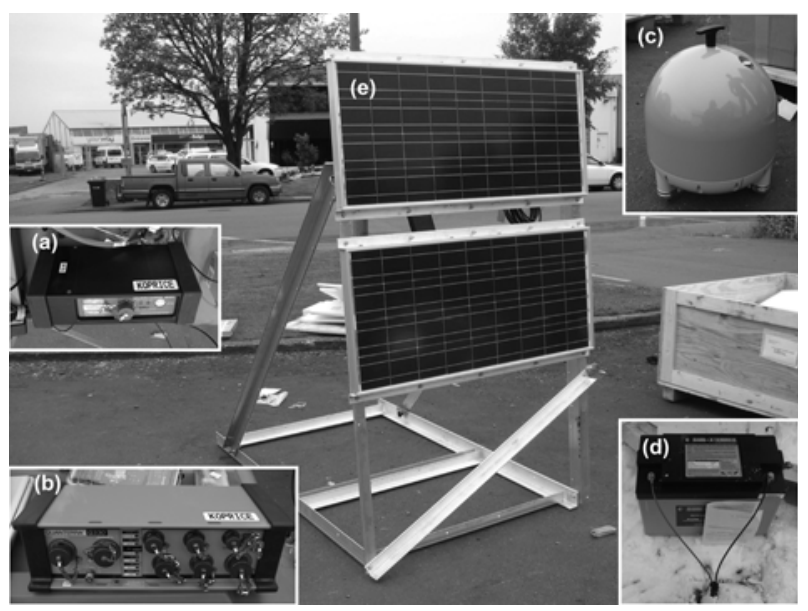

Fig. 2. The key components of an autonomous seismic station. (a) Baler44 manufactured by Quanterra. Dual removable industrial rated USB solid-state flash media implemented. The capacity of each media device is up to $16 \mathrm{~Gb}$, which is big enough to record three component seismic data for a year with $100 \mathrm{~Hz}$. (b) Quanterra Q330 digitizer. It is able to reliably operate at exceedingly low temperature. The Q330 is a 24 bit, 6 channel digitizer. (c) Nanometrics Trillium 240 seismograph that is a symmetric triaxial broadband instrument. It could perform perfectly at temperatures even below $-60{ }^{\circ} \mathrm{C}$. (d) The AGM deep cycle battery (PVX-1080T) manufactured by Sun Xtender. In total 8 PVX-1080Ts and 2 PVX-340Ts are equipped for each seismic station. (e) Solar panels are used for supplying electric power. It helps to constantly operate a seismic station incorporating with gel cell batteries. 

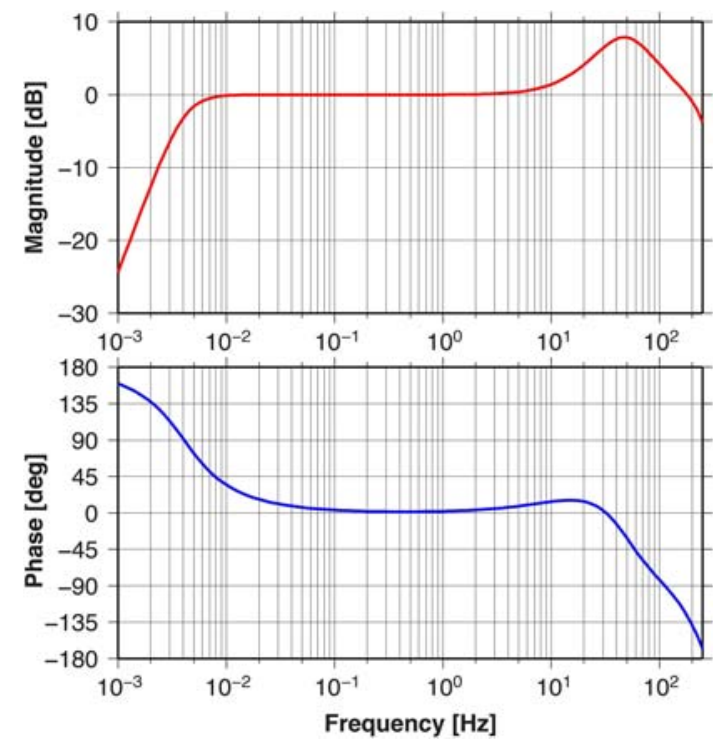

Fig. 3. The frequency response of the Trillium 240. Red and blue curves are amplitude and phase responses, respectively. Note that the amplitude shows a flat response over bandwidth between $240 \mathrm{~s}$ and $200 \mathrm{~Hz}$, which allows us to study local and global earthquakes.

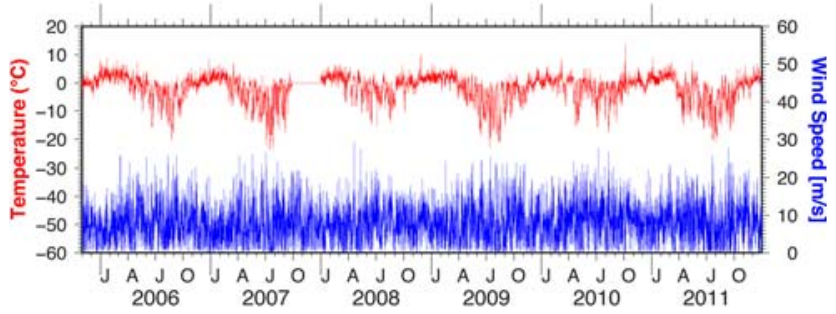

Fig. 4. Observation of temperature and wind speed collected from a meteorological station at KSJ for the period of $2006 \sim$ 2011. Temperature data from October through December 2007 is missing due to malfunctioning of a thermometer. Seasonal maximum of temperature is about $10{ }^{\circ} \mathrm{C}$ during the austral summer, and it reaches down to about $-20^{\circ} \mathrm{C}$ in July and August. Average wind speed is $8.1 \mathrm{~m} / \mathrm{s}$, and it shows seasonal variability becoming stronger in the austral winter and weaker in the austral summer.

mum temperature at King Sejong Station for the past ten years $\left(\sim-20^{\circ} \mathrm{C}\right.$, see Fig. 4$)$, the sensor should be functioning normally year round.

\section{Data logging system}

To record seismic data during the extremely cold Polar nights, Polar seismologists and research groups (e.g. IRIS PASSCAL Polar Group) tend to rely on the Quanterra Q330 digitizer, which is 24 bit, due to its exceedingly low temperature tolerance. Quanterra also provides a cold rated version of Q330, and it gives us an opportunity to run a seismic system down to $-45^{\circ} \mathrm{C}$. In addition to its very low temperature

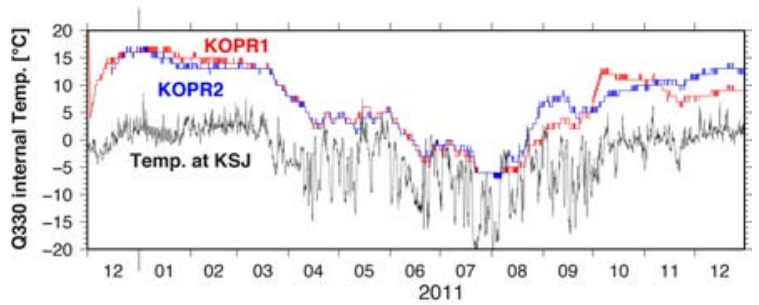

(a)

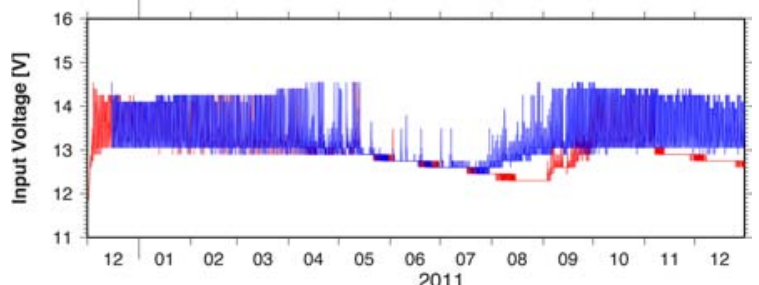

(b)

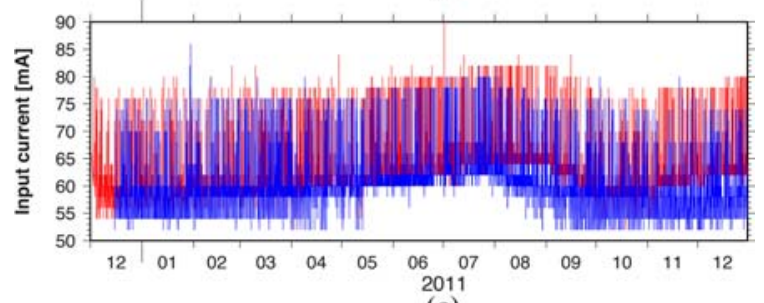

(c)

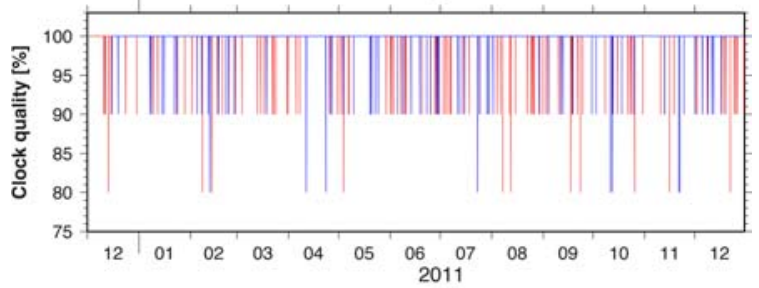

(d)

Fig. 5. System State-Of-Health information. (a) Air temperature at KSJ (black curve) vs. Q330 internal temperature for KOPR1 (red curve) and KOPR2 (blue curve) during the operation period. The minimum internal temperature is about $-7{ }^{\circ} \mathrm{C}$ in early August. (b) Even during the dark winter months, input voltage remains above $12.5 \mathrm{~V}$. (c) Input current in mA. (d) System clock quality. Mostly timing quality keeps higher than $90 \%$. In general, time is guaranteed correct for any value $60 \%$ or higher. If LCQ is less than $10 \%$, the time is meaningless.

tolerance, its very low power consumption makes it ideal for year round experiments in the Antarctic deep field (http:// www.passcal.nmt.edu). The data is recorded on an external Baler unit (B44) which contains two industrial rated thumb drives ( $8 \mathrm{~Gb}$ each). We have collected seismic data with 1 (LHX) and $100 \mathrm{~Hz}$ (HHX) sampling rates. Besides recording seismic waveform data, Q330 provides useful State-OfHealth (SOH) information (e.g., GPS location, input voltage, current, internal temperature of the device, etc.; Fig. 5) which helps to assess data quality. The $\mathrm{SOH}$ information and short waveforms recorded on a system buffer could be dis- 


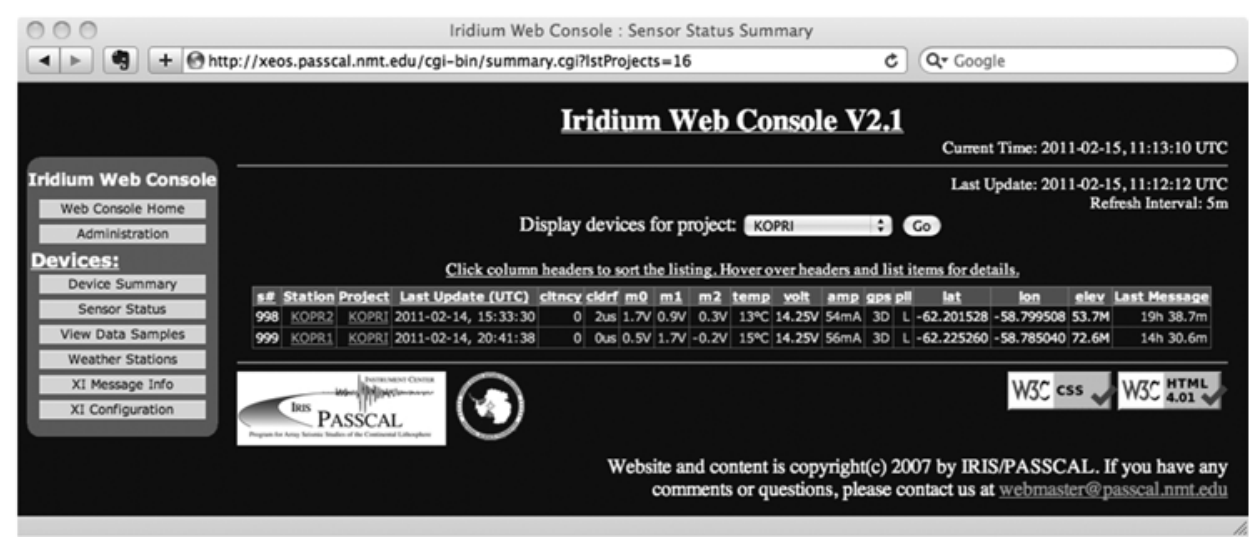

Fig. 6. Website (http://xeos.passcal.nmt.edu) maintained by Xeos Technology Inc., which informs us of various operation parameters.

patched to authorized operators or scientists via E-mail using satellite communication if an IRIDIUM modem (e.g., XI100B; http://www.xeostech.com) has been attached to the system. Currently, Short Burst Data (SBD) including the information has been delivered to scientists at KOPRI and PASSCAL twice a day. One can review the status through the Xeos website (http://xeos.passcal.nmt.edu; Fig. 6).

\section{Power system}

Robust and stable power system plays the most crucial role in the operation of autonomous seismic stations in Polar Regions. The PASSCAL Polar Group has chosen to use SunXtender AGM batteries produced by Concord (http:// www.sunxtender.com) for solar charging systems. The robustness and reliability of the batteries have been verified from many deployments in Polar Regions, especially Antarctica. We used 2 of PVX-340T and 8 of PVX-1080T batteries for a year round seismic station. To recharge them, we mounted a high power solar panel system consisting of two $80 \mathrm{~W}$ Sharp NE-80EJEA panels and double wall aluminum frames that enable the entire system to be safe even against blizzard during the operation period. Fig. 5 (b) and (c) represent that the power system has provided reliable power consecutively even during the dark austral winter months (min. air temperature $\sim-20{ }^{\circ} \mathrm{C}$ ). Fig. 7 shows assembled components of a seismic system inside an insulated box.

\section{Background Noise}

Prior to intensive investigation, we tend to conduct background noise analysis to evaluate station performance and to examine the evolution of seismic noise (e.g., Aster et al., 2008). McNamara and Buland (2004) introduced a powerful

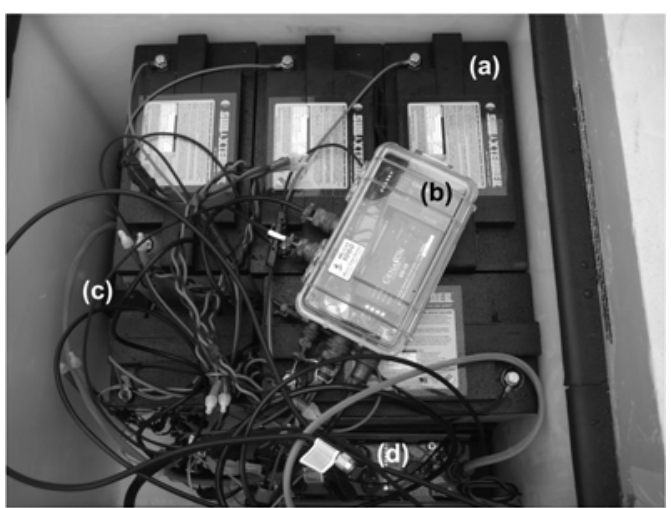

Fig. 7. Assembled components placed into a highly insulated enclosure. (a) Rechargeable batteries, (b) power switcher, (c) Baler44, and (d) Q330. An Iridium modem was added into the box afterwards. Mil-spec cables and connectors are used.

method, which facilitates estimating the power spectral densities (PSD), and then we construct probability density functions (PDF) to investigate the highest probability noise level (mode) for each channel as a function of period. The biggest advantage of the method is that there is no need to screen the data for system transients, damaging earthquakes, or general data artifacts because they are not significant compared to background noise in terms of probability (McNamara and Buland, 2004). Another useful feature of the method at an operational point of view is that it enables us to check if the system response is written correctly, which is quite important to maintain seismic stations. Fig. 8 shows plots for PDF (KOPR1) for the month of March 2011 (upper left; vertical component), recorded time traces used for PSD calculation (upper right), their corresponding PSDs (bottom left) and start times (bottom right). Temporal variation of seismic noise for three components at KOPR1 is shown in Fig. 9. Although the great Tohoku earthquake $\left(M_{W}\right.$ 9.0; Fig. 10) 


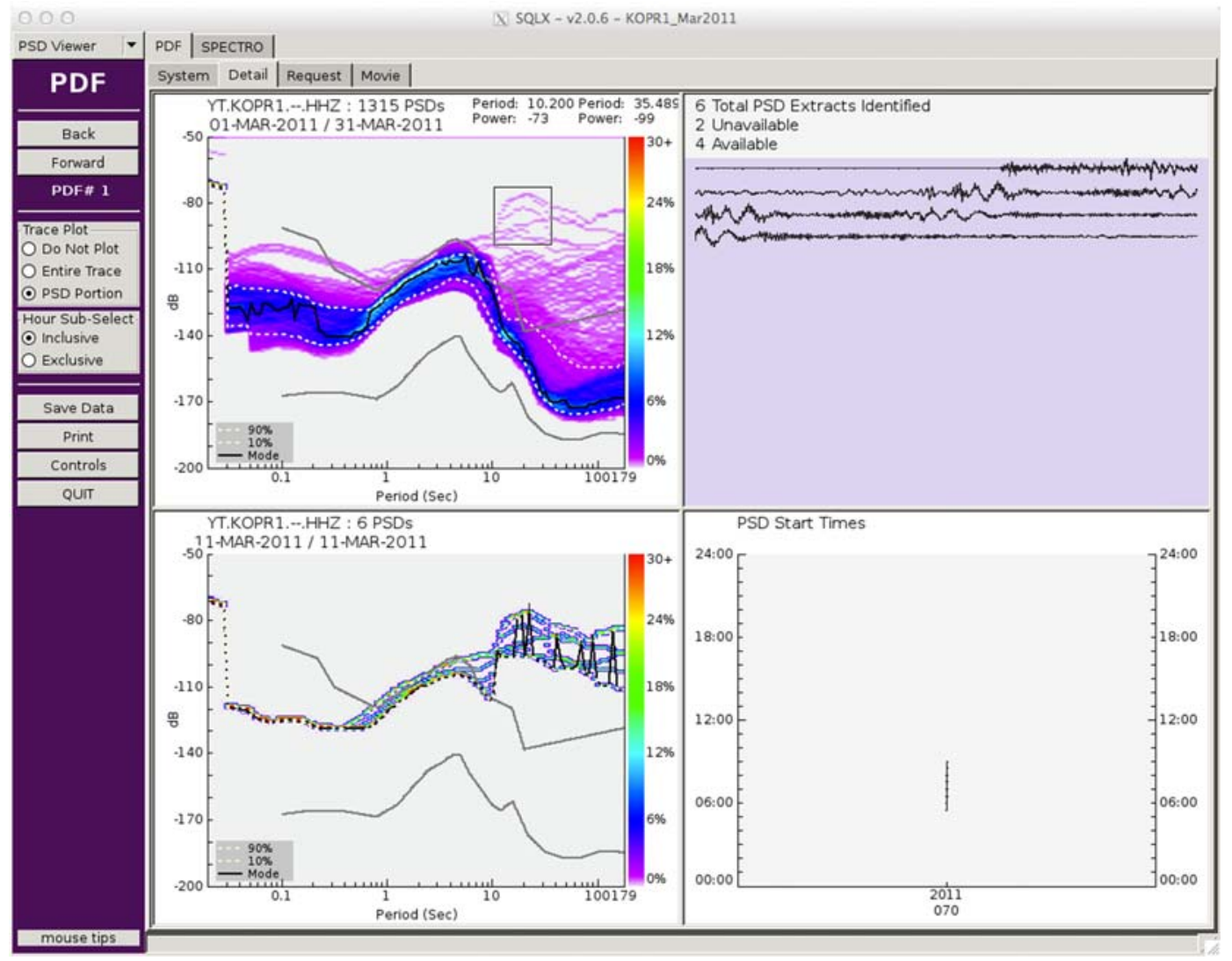

Fig. 8. The PDF plot for the month of March 2011 (03/01 03/31; KOPR1). The upper left panel displays system PDF with a subselect bounding box. The lower left panel shows the resultant PDF of PSDs intersecting the bounding box defined between periods of 10.2 to 35.5 seconds, and -73 to $-99 \mathrm{~dB}$ (The great Tohoku earthquake). The lower right panel is a histogram displaying the start times of the intersecting PSDs. The upper right panel displays the source traces for the intersecting PSDs.

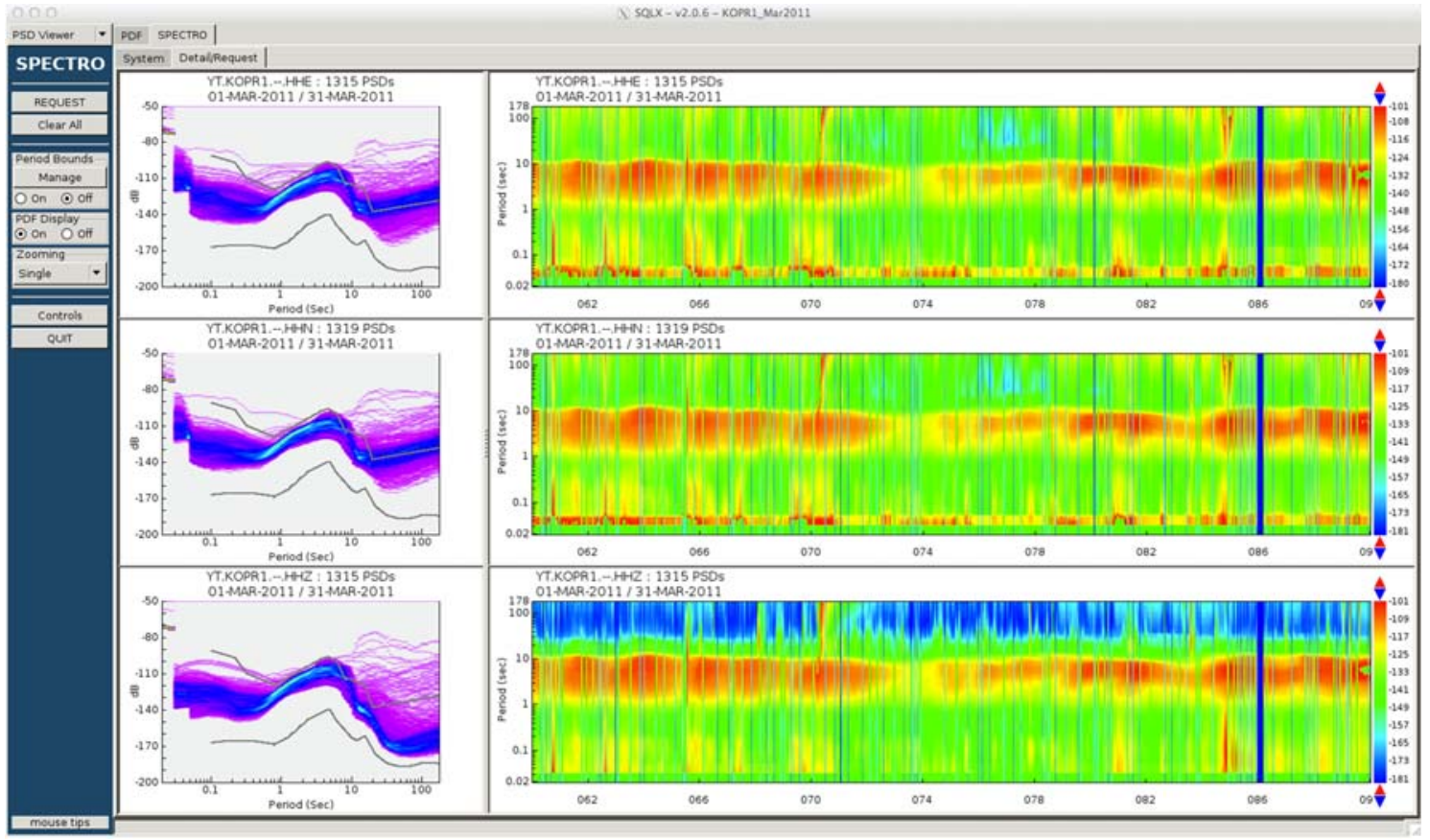

Fig. 9. PDF plots for three components (HHE, HHN, and HHZ from top to bottom) for the same period as Fig. 8. Right panels represent temporal variation of seismic noise amplitude. Note that strong low frequency energy shows up on March 11 (Julian date 70), which is associated with the Tohoku earthquake. 


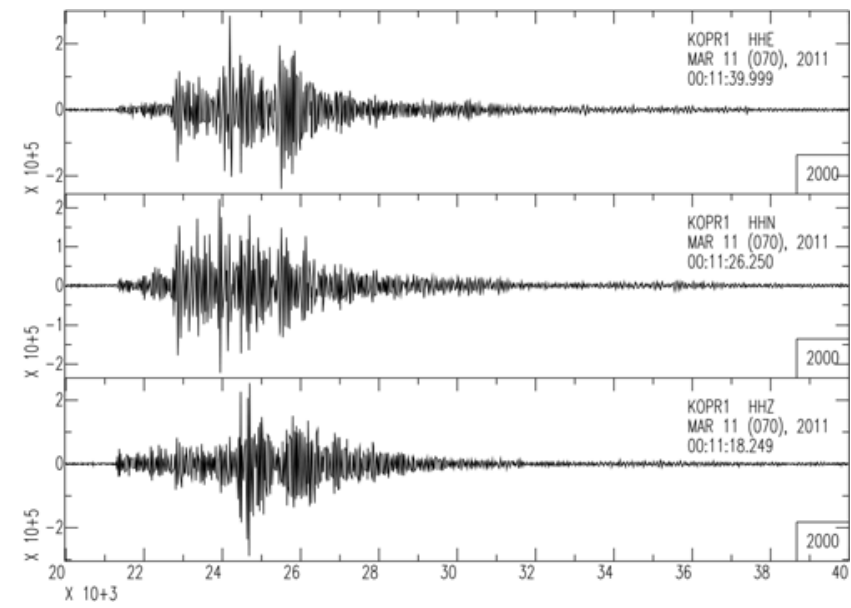

Fig. 10. Bandpass filtered $(0.01 \sim 25 \mathrm{~Hz})$ three-component seismograms at KOPR1 for the Tohoku earthquake.

occurred on March 11, 2011, which energy is dominant at a low frequency range (inside of a rectangular box, upper left of Fig. 8), it doesn't affect significantly the PDF since it happens much less frequent than any other signals or noises. Compared to the standard high-noise and low-noise models (HNM and LNM; Peterson, 1993), the overall performance of the station is fairly normal so that the recorded data should be reliable to use even the peak of the double-frequency microseism reaches closely to the HNM in March 2011.

\section{Summary and Future Direction}

In Polar seismology, we are commonly faced with several challenges, for instance, extreme cold conditions and inaccessibility. Recent development in polar technology such as lowpower circuits, extended battery life, etc. gives us more opportunities to investigate not only tectonic features but also fascinating phenomena associated with cryospheric environment.

KOPRI has successfully installed and been operating two very broadband autonomous seismic stations at the KGI. As mentioned in the previous chapters, the observation systems we built function normally under the harsh environment. The solar power system stably provides electric power to the whole system even during the dark winter months. Very broadband frequency coverage of seismographs allows us to examine from global to local tectonic events as well as cryogenic signals, which offers a unique chance to investigate physical interaction between solid Earth and cryospheric environment. As we validated the robustness of the seismic observation system in Antarctica, we are going to move

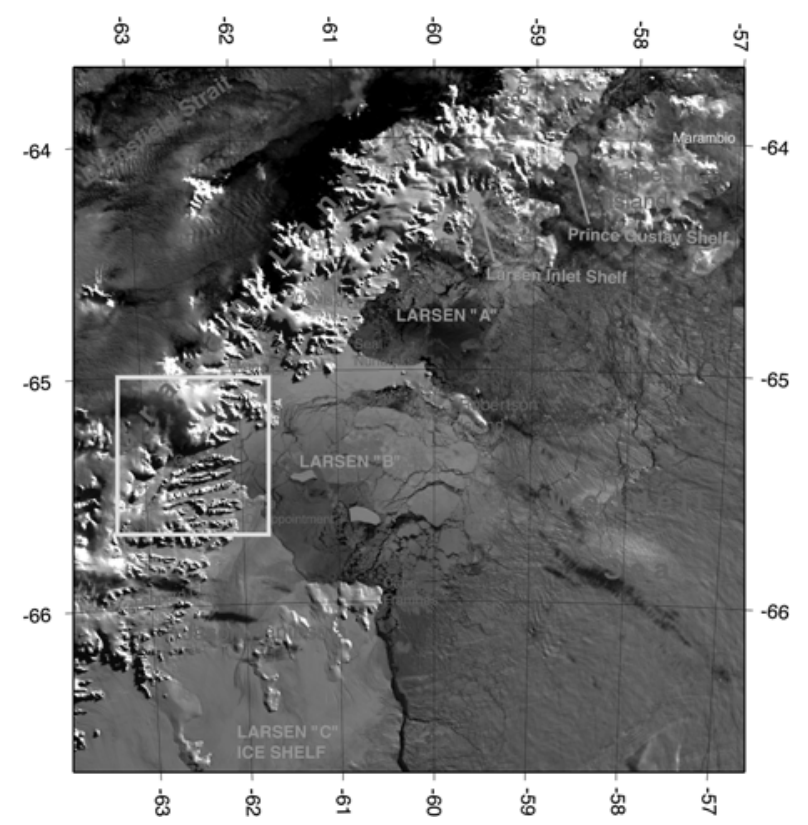

Fig. 11. Possible installation location (inside of a yellow box) of seismic stations in the Antarctic Peninsula.

them adding a couple more stations into near the Larsen B Ice shelf (Fig. 11) in an attempt to assess the stability of the ice shelf system in 2013.

\section{Acknowledgments}

We thank for outstanding logistical support by S.H. Kang and H.C. Shin, and B. Cho for zodiac and snowmobile operation at King Sejong Station. T. Parker (IRIS PASSCAL) has provided valuable technical advice and hardware for our station installation. This research has been supported by KOPRI Grants PP12020, PE12310, and PE12050.

\section{References}

Aster, R. C., D. E. McNamara, and P. D. Bromirski, 2008, Multidecadal Climate-induced Variability in Microseisms, Seismological Research Letters, 79(2), 194-202.

Dziak, R. P., M. Park, W. S. Lee, H. Matsumoto, D. R. Bohnenstiehl, and J. H. Haxel, 2010, Tectonomagmatic activity and ice dynamics in the Bransfield Strait back-arc basin, Antarctica, Journal of Geophysical Research, 115(B1), $1-14$.

McNamara, D. E., and R. P. Buland, 2004, Ambient Noise Levels in the Continental United States, Bulletin of the Seismological Society of America, 94(4), 1517-1527.

Peterson, J., 1993, Observation and modeling of seismic background noise, U.S. Geological Survey Technical Report, 93-322, 1-95. 